


\section{Training Restrictions on Army Lands Due to High Priority Endangered Species}

Patrick J. Guertin

Construction Engineering Research Laboratory

PO Box 9005

Champaign, IL 61826-9005

Final Report

Approved for public release; distribution is unlimited.

Prepared for U.S. Army Corps of Engineers

Washington, DC 20314-1000 
ABSTRACT: The Endangered Species Act requires that Federal agencies conserve Threatened and Endangered Species (TES), and in consultation with the U.S. Fish and Wildlife Service or the National Marine Fisheries Service, ensure their actions are not likely to jeopardize the continued existence of any TES or result in the destruction or adverse modification of critical habitat. Guidance for TES management can produce restrictions that interfere with realistic combat training conducted on Army installations.

The U.S. Army Environmental Requirements and Technology Assessments (AERTA) research is focused on seven of the highest priority TES. These species are: red-cockaded woodpecker (Picoides borealis), black-capped vireo (Vireo atricapillus), golden-cheeked warbler (Dendroica chrysoparia), gray bat (Myotis grisescens), Indiana bat (Myotis sodalis), desert tortoise (Gopherus agassizii), and gopher tortoise (Gopherus polyphemus).

This document provides a current depiction of TES-related restrictions on Army installations that have populations of the seven priority TES and are, or have been, the focus of ERDC-CERL research efforts. Two important conclusions can be drawn from the information presented in this report: (1) TES restrict military training on installations to a quantifiable degree, and (2) over time, there is potential for many of these restrictions to be reduced.

DISCLAIMER: The contents of this report are not to be used for advertising, publication, or promotional purposes.

Citation of trade names does not constitute an official endorsement or approval of the use of such commercial products.

All product names and trademarks cited are the property of their respective owners. The findings of this report are not to be construed as an official Department of the Army position unless so designated by other authorized documents.

DESTROY THIS REPORT WHEN IT IS NO LONGER NEEDED. DO NOT RETURN IT TO THE ORIGINATOR. 


\section{Contents}

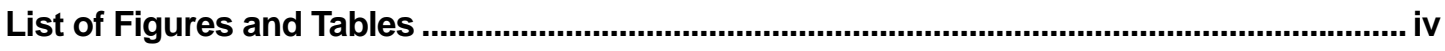

Conversion Factors ........................................................................................................... v

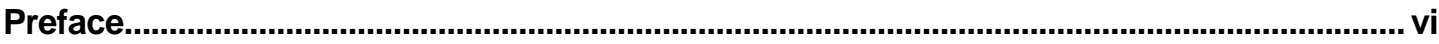

1 Introduction ............................................................................................................... 1

Background $\ldots \ldots \ldots \ldots \ldots \ldots \ldots \ldots \ldots \ldots \ldots \ldots \ldots \ldots \ldots \ldots \ldots \ldots \ldots \ldots \ldots \ldots \ldots \ldots \ldots \ldots \ldots \ldots \ldots \ldots \ldots \ldots \ldots 1$

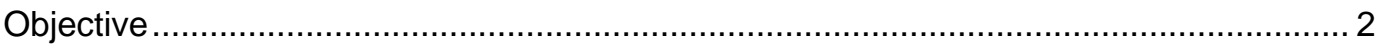

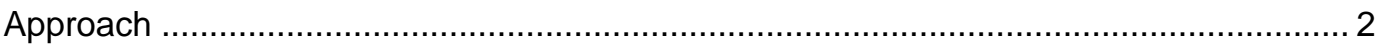

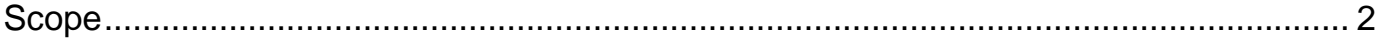

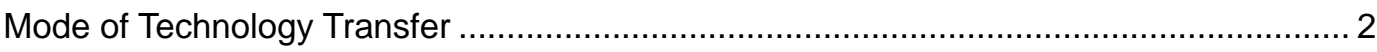

2 Threatened and Endangered Restriction Review ..................................................... 3

Red-cockaded woodpecker (Picoides borealis) - Federal Status: Endangered .............. 3

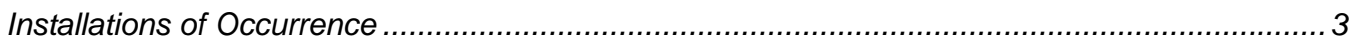

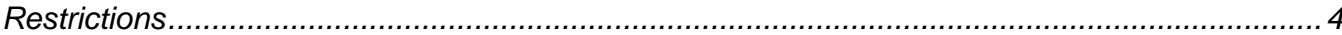

Black-capped vireo (Vireo atricapillus) and golden-cheeked warbler (Dendroica

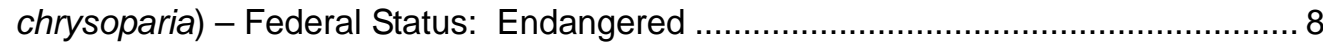

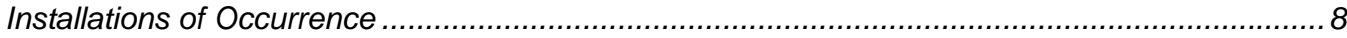

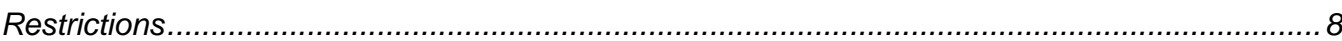

Gray bat (Myotis grisescens) and Indiana bat (Myotis sodalis) - Federal Status:

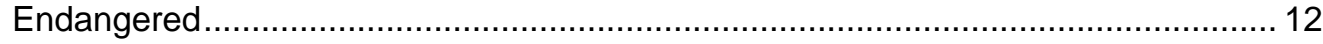

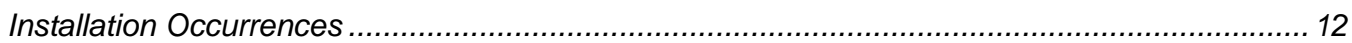

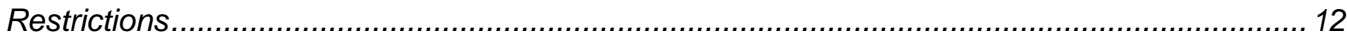

Desert tortoise (Gopherus agassizii)- Federal Status: Threatened ............................. 15

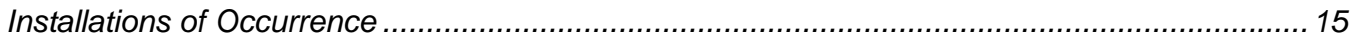

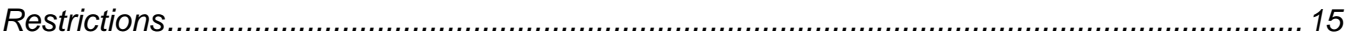

Gopher tortoise (Gopherus polyphemus) - Federal Status: Threatened .................... 17

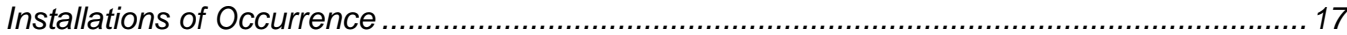

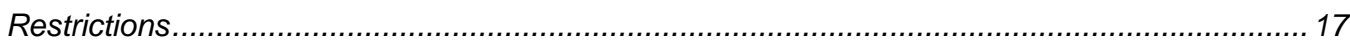

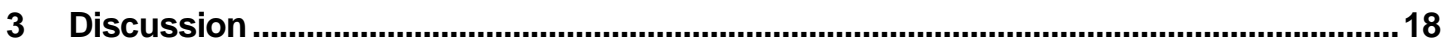

Literature Cited..........................................................................................................................20

REPORT DOCUMENTATION PAGE ....................................................................................... 22 


\section{List of Figures and Tables}

\section{Figures}

1. Potential breeding group trends across major Army installations............................. 7

2. Current areas of Fort Hood, TX, with training restrictions due to BCV and GCW....... 9

3. Areas of Fort Hood, TX, with training restrictions to BCV and GCW if proposed

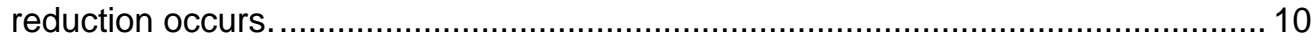

4. Buffer Zones (wide black strips) for TPA smoke restrictions along waterways,

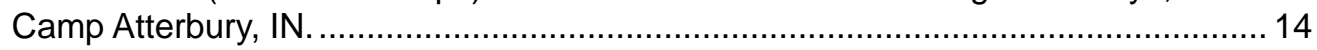

5. Fort Leonard Wood endangered bat related restrictions, left image depicts TPA smoke buffers on waterways and zones around gray bat maternity caves, right image depicts zones around Indiana bat hibernacula (caves)................................ 14

6. Locations of desert tortoise conservation areas on Fort Irwin, CA ............................ 16

\section{Tables}

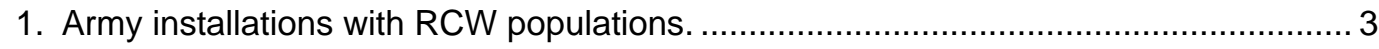

2. RCW population statistics presented at the 2004 USFWS/Army RCW

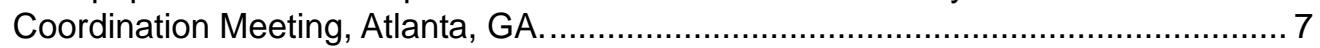

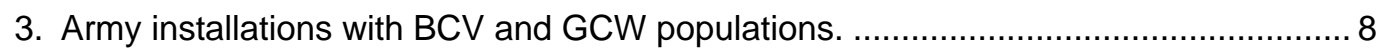

4. Installations with gray and Indiana bat populations.............................................. 12

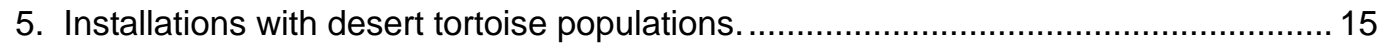




\section{Conversion Factors}

Non-SI* units of measurement used in this report can be converted to SI units as follows:

\begin{tabular}{|c|c|c|}
\hline Multiply & By & To Obtain \\
\hline acres & $4,046.873$ & square meters \\
\hline cubic feet & 0.02831685 & cubic meters \\
\hline cubic inches & 0.00001638706 & cubic meters \\
\hline degrees (angle) & 0.01745329 & radians \\
\hline degrees Fahrenheit & $(5 / 9) \times\left({ }^{\circ} \mathrm{F}-32\right)$ & degrees Celsius \\
\hline degrees Fahrenheit & $(5 / 9) \times\left({ }^{\circ} \mathrm{F}-32\right)+273.15$ & kelvins \\
\hline feet & 0.3048 & meters \\
\hline gallons (U.S. liquid) & 0.003785412 & cubic meters \\
\hline horsepower (550 ft-lb force per second) & 745.6999 & watts \\
\hline inches & 0.0254 & meters \\
\hline kips per square foot & 47.88026 & kilopascals \\
\hline kips per square inch & 6.894757 & megapascals \\
\hline miles (U.S. statute) & 1.609347 & kilometers \\
\hline pounds (force) & 4.448222 & newtons \\
\hline pounds (force) per square inch & 0.006894757 & megapascals \\
\hline pounds (mass) & 0.4535924 & kilograms \\
\hline square feet & 0.09290304 & square meters \\
\hline square miles & $2,589,998$ & square meters \\
\hline tons (force) & $8,896.443$ & newtons \\
\hline tons ( 2,000 pounds, mass) & 907.1847 & kilograms \\
\hline yards & 0.9144 & meters \\
\hline
\end{tabular}

\footnotetext{
*Système International d'Unités ("International System of Measurement"), commonly known as the "metric system."
} 


\section{Preface}

This study was conducted for the Office of the Director of Environmental Programs under Project A897, "Base Facility Environmental Quality," "Threatened and Endangered Species Project Management." The technical monitor was Bill Woodson (DAIM-ED-N).

The work was performed by the Ecological Processes Branch (CN-N) of the Installations Division (CN), Construction Engineering Research Laboratory (CERL). The CERL Principal Investigator was Patrick J. Guertin. Steven Hodapp is Chief, CEERD-CN-N and Dr. John T. Bandy is Chief, CEERD-CN. The associated Technical Director was Dr. William D. Severinghaus, CEERD-CV-T. The Director of CERL is Dr. Alan W. Moore.

CERL is an element of the U.S. Army Engineer Research and Development Center (ERDC), U.S. Army Corps of Engineers. The Commander and Executive Director of ERDC is COL James R. Rowan, and the Director of ERDC is Dr. James R. Houston. 


\section{Introduction}

\section{Background}

The Endangered Species Act (ESA) requires that Federal agencies conserve Threatened and Endangered Species (TES), and in consultation with the U.S. Fish and Wildlife Service (USFWS) or the National Marine Fisheries Service (NMFS), ensure their actions are not likely to jeopardize the continued existence of any TES or result in the destruction or adverse modification of critical habitat (ESA 1973). USFWS Biological Opinions and other guidance for TES management can produce restrictions that interfere with realistic combat training conducted on Army installations. The Engineering Research and Development Center-Construction Engineering Research Laboratory (ERDC-CERL) is undertaking a research program designed to address these restrictions.

Direction for the ERDC-CERL TES research program is provided by the U.S. Army Environmental Requirements and Technology Assessments (AERTA) web site on the Internet (http://aec.army.mil/usaec/technology/aerta.html). This web site sets forth basic user requirements and exit criteria. ${ }^{*}$ TES-related restrictions are covered under Requirement A(4.6.a): "Reducing Impacts of Threatened and Endangered Species (TES) on Military Readiness". In general, this requirement is designed to provide quantitative information on the relationships between Army mission-related training and testing and the conservation of high-priority species.

AERTA research is focused on seven of the highest ranked (priority) TES. These species are: red-cockaded woodpecker (Picoides borealis), black-capped vireo (Vireo atricapillus), golden-cheeked warbler (Dendroica chrysoparia), gray bat (Myotis grisescens), Indiana bat (Myotis sodalis), desert tortoise (Gopherus agassizii), and gopher tortoise (Gopherus polyphemus).

\footnotetext{
* Detailed user requirements and exit criteria are available on the Defense Environmental Network Information eXchange (DENIX) web site at https://www.denix.osd.mil/denix/DOD/Policy/Army/AERTA/tnstop.html — a DENIX account is required.
} 


\section{Objective}

The objective of this research is to provide a current depiction of TES-related restrictions on Army installations that have populations of the seven priority TES and are, or have been, the focus of ERDC-CERL research efforts.

\section{Approach}

The approach undertaken to develop this document consisted of a review of in-house materials; and available external documents, pertinent to the status of TES-related training restrictions on Army installations within the purview of ERDC-CERL research efforts. Restrictions on nontraining activities, such as forest management, mowing, and agricultural out-lease, are not covered. Data presented in this document is derived from several sources including (but not limited too): USFWS Biological Opinions, biological assessments, ERDC-CERL technical and programmatic documents, and installation natural resources management plans (INRMPs). As there is no central repository for data regarding TES-related restrictions on Army lands, data for some installations is missing or may have gaps, but all data presented was the most current at time of document preparation.

\section{Scope}

Results from this report apply directly to Army installations identified in this report.

\section{Mode of Technology Transfer}

This document will lead to the development of future research plans to address TES-related training restrictions on military installations.

This report will be made accessible through the World Wide Web (WWW) at URL: http://www.cecer.army.mil 


\section{Threatened and Endangered Restriction Review}

Each of the following sections covers an individual or a pair of TES listed in the priority seven species. Each section lists the installations of occurrence and the restrictions the species have placed on military training for specific installations. TES impacts are not all inclusive of the installations listed for all species. For some species, training restrictions represent examples of what is occurring on installations where data are available and potential impacts of TES effects on training for other installations where populations are found.

\section{Red-cockaded woodpecker (Picoides borealis) - Federal Status: Endangered}

\section{Installations of Occurrence}

As reported in Installation Summaries from the FY 2003 Survey of Threatened and Endangered Species on Army Lands (Rubinoff et al. 2004), 11 Army installations have populations of RCW within or adjacent to their boundaries (Table 1).

Table 1. Army installations with RCW populations.

\begin{tabular}{|l|l|l|}
\hline Installation & IMA & Location \\
\hline Camp Beauregard, LA & ARNG & Contiguous \\
\hline Camp Blanding, FL & ARNG & Onsite \\
\hline Camp Shelby, MS & ARNG & Contiguous \\
\hline Leesburg Training Site, SC & ARNG & Onsite \\
\hline Fort Polk, LA & SW & Onsite \\
\hline Fort Bragg, NC & SE & Onsite \\
\hline Fort Stewart, GA & SE & Onsite \\
\hline $\begin{array}{l}\text { Military Ocean Terminal- } \\
\text { Sunny Point, NC }\end{array}$ & SE & Onsite \\
\hline Fort Benning, GA & SE & Onsite \\
\hline Fort Gordon, GA & SE & Onsite \\
\hline Fort Jackson, SC & SE & Onsite \\
\hline
\end{tabular}




\section{Restrictions}

Except for minimal organizational modifications, the following are training restrictions as presented in the 1996 "Management Guidelines for the Red-cockaded Woodpecker on Army Installations." These restrictions apply to all Army installations with RCW populations. RCW Management and restrictions are centered on clusters (formerly called colonies), which are the aggregate areas encompassing cavity trees and a surrounding 200-foot buffer that is or was used by one RCW, a mated pair, or a mated pair with helper birds.

\section{Training within RCW clusters}

1. RCW and RCW habitat will be managed biologically by clusters. Training restrictions will apply to marked buffer zones around cavity trees (buffer zones are 200 feet from marked cavity trees).

2. The training restrictions in this section apply to buffer zones within marked active clusters and primary recruitment clusters. RCW training restrictions do not apply to supplemental recruitment clusters, inactive clusters, and foraging areas.

3. Standard training guidelines within active clusters and primary recruitment clusters:

(a) Military training within marked cavity tree buffer zones is limited to military activities of a transient nature (less than 2 hour occupation). The following are permitted activities:

\section{Maneuver and Bivouac}

- Hasty defense, light infantry, hand digging only, 2 hour max

- Foot transit thru colony

- Wheeled vehicle transit thru the colony*

- Armored vehicle transit thru the colony*

- Cutting natural camouflage, hard wood only

- Vehicle maintenance for no more than 2 hours

\footnotetext{
* Vehicles will not get any closer than 50 feet of a marked cavity tree unless on existing roads, trails, or firebreaks.
} 


\section{Weapons firing}

- $7.62 \mathrm{~mm}$ and below blank firing

- .50 cal blank firing

Noise

- Artillery/Hand grenade simulators

- Hoffman type devices

Pyrotechnics/Smoke

- Smoke, haze operations only, generators or pots*

- Smoke grenades

- Star clusters/parachute flares

Digging

- Hasty individual fighting positions, hand digging only, filled after use

(b) Military vehicles are prohibited from occupying a position or traversing within 50 feet of a marked cavity tree, unless on an existing road, trail, or firebreak.

\section{Training throughout the installation}

In addition to restrictions listed above for activities within clusters, the following also apply to military activities on the installation.

1. Military personnel are prohibited from cutting down or intentionally destroying pine trees unless the activity is approved previously by the installation biologist and/or forester and is authorized for tree removal. Hardwoods may be cut and used for camouflage or other military purposes.

2. Units will immediately report to range control known damage to any marked cavity or cavity start tree and/or any known extensive soil disturbance in and around RCW clusters.

3. The installation will immediately (within 48 hours) reprovision a cavity tree if one is destroyed.

\footnotetext{
* Smoke generators and smoke pots will not be set up within 200 feet of a marked cavity tree, but the smoke may drift through the $200-f t$ circle around a cavity tree.
} 
4. Installations will as soon as practicable (normally within 72 hours) repair damage to training land within a cluster to prevent degradation of habitat.

5. All digging for military activities in suitable acreage will be filled in within a reasonable time after the completion of training.

6. Training guidelines will be actively enforced through installation training and natural resources enforcement programs, prescribed in Army Regulation (AR) 200-3 (28 February 1995), chapters 1 and 11, and installation range regulations.

The above listed training restrictions largely limit Army training within cluster areas to light activities of limited time duration. For example, deliberate defensive exercises that may require more than hand-dug entrenchments (i.e., entrenching of vehicles) and would most likely last for periods longer than 2 hours, and firing the main armaments of Bradley infantry fighting vehicles or Abrams tanks (both weapons exceed .50 caliber) are prohibited.

The 1996: Management Guidelines for the Red-cockaded Woodpecker on Army Installations, replaced 1994 Army Guidelines for RCW Management. The newer guidelines had a potential significant effect on loosening training restrictions around clusters. The 1994 Guidelines required buffer zones of 200 feet from "aggregate areas" containing active or inactive cavity trees. The 1996 guidelines specify buffer zones of 200 feet from cavity or cavity start "trees" within active clusters and primary recruitment clusters. The redefining of buffer zones allows for greater access to areas containing cavity trees by units training (Hayden 1997). Additionally, the 1996 Guidelines allow vehicles to traverse within 50 feet of cavity trees on existing roads. New designations of Secondary Recovery Clusters (SRCs) allows for new clusters on installations without increasing training restrictions, as restrictions do not apply to SRCs.

Available RCW population data for 1997 and 2003 and population recovery goals are presented in Table 2 . Long-term population trends across all installations reporting at the 2004 USFWS/Army RCW Coordination Meeting showed increases in population sizes (Figure 1). 
Table 2. RCW population statistics presented at the 2004 USFWS/Army RCW Coordination Meeting, Atlanta, GA.

\begin{tabular}{|c|c|c|c|c|c|c|c|c|c|c|}
\hline \multirow[b]{2}{*}{ Installation } & \multicolumn{6}{|c|}{ 1997-2003 Population Data } & \multicolumn{4}{|c|}{ Population Goals } \\
\hline & \begin{tabular}{|l}
1997 Total \\
Active \\
Clusters
\end{tabular} & \begin{tabular}{|l|}
1997 \\
Total \\
PBG*
\end{tabular} & \begin{tabular}{|l}
2003 Tota \\
Active \\
Clusters
\end{tabular} & $\begin{array}{l}2003 \\
\text { Total } \\
\text { PBG* }\end{array}$ & \begin{tabular}{|l}
2003 \\
${ }^{*}$ PRC* \\
\end{tabular} & \begin{tabular}{|l}
2003 \\
SRC*
\end{tabular} & \begin{tabular}{|l}
$\mid$ Total \\
Active \\
Clusters
\end{tabular} & \begin{tabular}{|l} 
Total \\
PBG*
\end{tabular} & PRC* & SRC* \\
\hline Fort Stewart, GA & 175 & 158 & 268 & 236 & 292 & 63 & 500 & 350 & 411 & 89 \\
\hline Fort Bragg, NC & 282 & 226 & 384 & 310 & 349 & 35 & 482 & $350 * *$ & 401 & 81 \\
\hline Fort Benning, GA & 173 & 138 & 251 & 223 & & & 451 & 350 & 361 & 90 \\
\hline Fort Polk, LA & 70 & 61 & 83 & 69 & & & & $350 * *$ & & \\
\hline Fort Jackson, SC & 14 & & 29 & & & & & 25 & & \\
\hline Fort Gordon, GA & 1 & & 6 & & & & & 25 & & \\
\hline Camp Blanding, FL & 13 & & 16 & & & & & $25^{\star \star}$ & & \\
\hline
\end{tabular}

Number of RCW Potential Breeding Groups

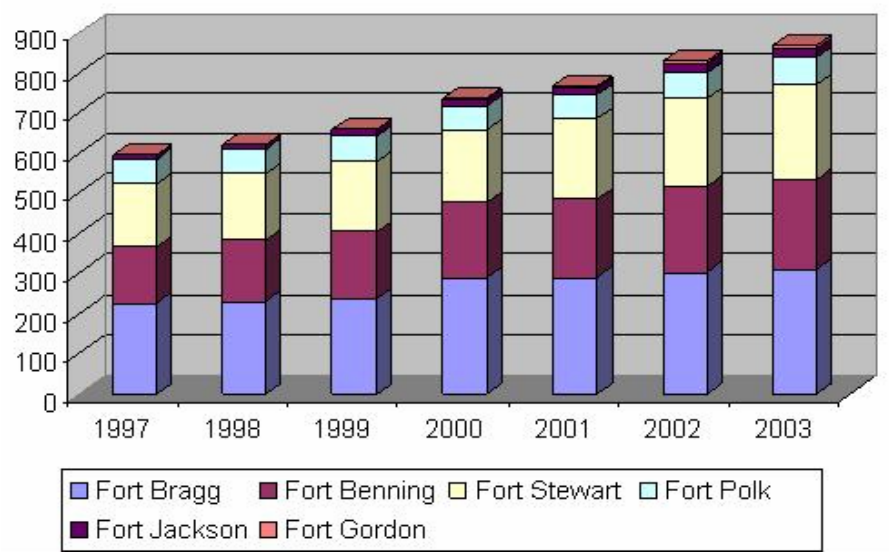

Figure 1. Potential breeding group trends across major Army installations. 


\section{Black-capped vireo (Vireo atricapillus) and golden-cheeked warbler (Dendroica chrysoparia) - Federal Status: Endangered}

\section{Installations of Occurrence}

Black-capped vireo (BCV) populations occur on four installations, and goldencheeked warbler (GCW) populations occur on two installations (Rubinoff et al. 2004). These installations are listed in Table 3.

Table 3. Army installations with BCV and GCW populations.

\begin{tabular}{|l|l|l|l|}
\hline Species & Installation & IMA & Location \\
\hline \multirow{4}{*}{$\begin{array}{l}\text { Black-capped } \\
\text { Vireo }\end{array}$} & Camp Bowie, TX & ARNG & Onsite \\
\cline { 2 - 4 } & Fort Hood, TX & SW & Onsite \\
\cline { 2 - 4 } & $\begin{array}{l}\text { Fort Sam Houston } \\
\text { (Camp Bullis), TX }\end{array}$ & SW & Onsite \\
\cline { 2 - 4 } & Fort Sill, OK & SW & Onsite \\
\hline \multirow{2}{*}{$\begin{array}{l}\text { Golden- } \\
\text { cheeked } \\
\text { Warbler }\end{array}$} & Fort Hood, TX & SW & Onsite \\
\cline { 2 - 4 } & $\begin{array}{l}\text { Fort Sam Houston } \\
\text { (Camp Bullis), TX }\end{array}$ & SW & Onsite \\
\hline
\end{tabular}

\section{Restrictions}

\section{Fort Hood}

Training restrictions related to black-capped vireo and golden-cheeked warbler as they apply to training activities at Fort Hood, Texas, are divided into Level 1 and Level 2 restrictions (Hayden et al. 2001). Restrictions apply to "core" species habitat.

\section{Level 1 Restrictions (applicable to core habitat from 1 September to 28} February)

1. Report all fires to range control, do not start fires.

2. Use previously established firing points, fighting positions, and emplacements only. All digging must be cleared by the Directorate of Public Works (DPW).

3. Comply with range rules regarding use of flares, incendiary munitions, etc. Ensure firefighting equipment and personnel on hand are in compliance with Fire Danger Rating SOP.

4. Park equipment in open areas only. Do not cut brush or trees for camouflage, road blocks, or other purposes. 
5. Use existing roads and trails. Do not drive vehicles through or over woody vegetation.

6. Do not tamper with, or release birds from cowbird traps.

\section{Level 2 Restrictions (applicable from 1 March through 31 August)}

1. All Level 1 restrictions apply.

2. Occupation of habitat areas is limited to drive-through on existing trails, or emergency stop only. No bivouac or other long-term posts are permitted within habitat areas. Long-term is defined as 2 hours in duration.

3. No use of obscurant smokes or other chemical agents in or within 100 meters of habitat.

Habitat acreage currently associated with each of these species include:

GCW: Total Habitat Available: $\quad 21,422$ ha (Hayden et. al. 2001)

Core Habitat: 14,871 ha (Hayden et. al. 2001)

BCV: $\quad$ Total Habitat Available: $\quad 6,967$ ha (Cimprich, 2003) Core Habitat: 4,184 ha (Hayden et. al. 2001)

Currently Fort Hood, with the assistance of ERDC/CERL, is preparing a Biological Assessment of Proposed Revision of the Fort Endangered Species Management Plan. The goals of this revision are to reduce core habitat of GCW to 3,861 ha and eliminate designated core habitat for BCV. Figures 2 and 3 show the extent of current restricted habitat and proposed changes.

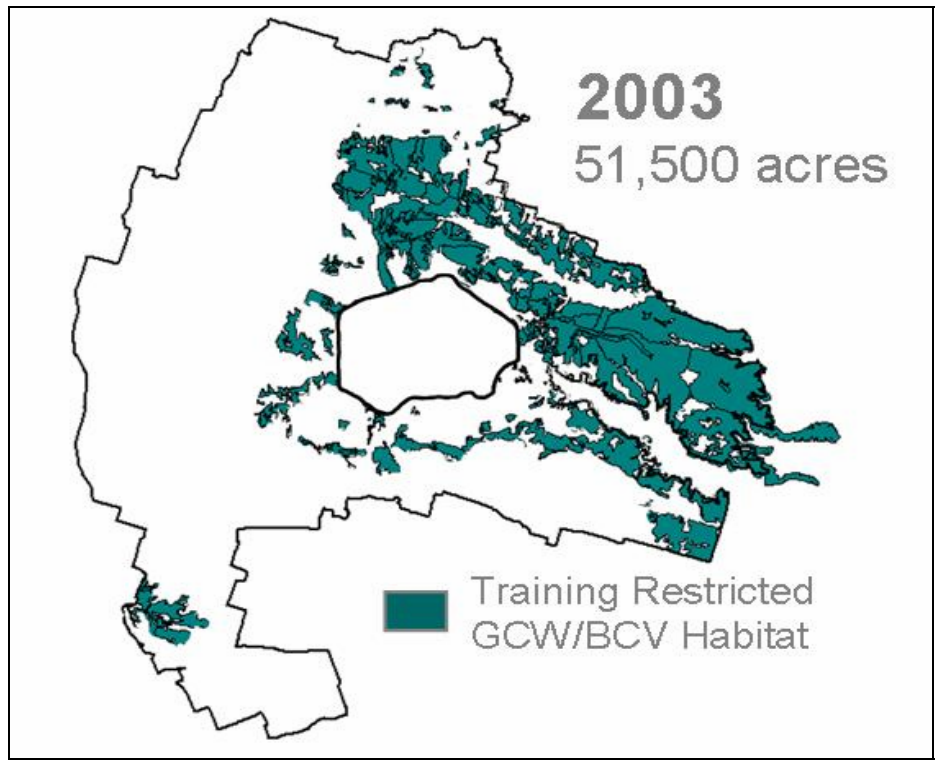

Figure 2. Current areas of Fort Hood, TX, with training restrictions due to BCV and GCW. 


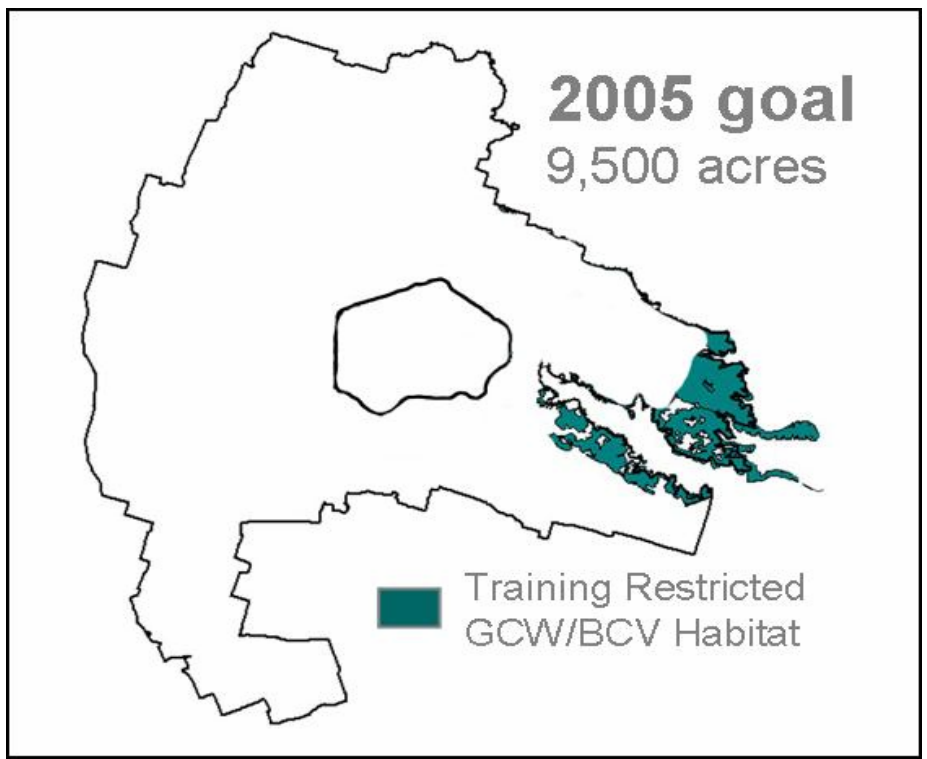

Figure 3. Areas of Fort Hood, TX, with training restrictions to BCV and GCW if proposed reduction occurs.

\section{Fort Sam Houston/Camp Bullis}

Training restrictions for black-capped vireo and golden-cheeked warbler as they apply to training activities at Fort Sam Houston/Camp Bullis, Texas, are contained in Fort Sam Houston regulation, AMEDDC\&S \& FSH 350-2, Camp Bullis Training, Chapter 5-3 g (2001).

g. Endangered species. Camp Bullis contains habitat supporting two federally listed threatened and endangered species: The golden cheeked warbler and the black capped vireo. In addition, three of the nine listed Bexar County invertebrates have been found on Camp Bullis. These species live in caves located throughout the installation and are afforded the same protection as the golden cheeked warbler and the black capped vireo. At no time will trash or other material including vegetation, soil, or rocks be placed in any cave, nor will any person enter any cave without prior authorization by the Camp Bullis commander. All threatened and endangered species and designated critical habitat are protected under the Endangered Species Act (ESA) of 1973, sections 1531 to 1544, title 16 United States Code (16 USC 1531-1544), a copy of the ESA is available at the ITAM Environmental Office, Camp Bullis. Violators of the ESA are subject to both civil and criminal penalties. Listing or de-listing is subject to change with little or no notice by the United States Fish and Wildlife Service (USFWS). It is Army policy to comply with the requirements of the ESA, and to ensure that all missionoriented activities are performed in harmony with the ESA. In order to con- 
serve and protect all applicable federally listed species and critical habitat, the following requirements have been established:

(1) All personnel using Camp Bullis will check with the ITAM Environmental Office, Camp Bullis (210-295-7761/7804), prior to beginning any training to determine all environmental constraints and restrictions that may impact their activities.

(2) Individuals will be responsible for knowing where all endangered species habitat or designated critical habitat areas are located relevant to their activities. Current endangered species habitat maps may be obtained at the ITAM, Environmental Office, Camp Bullis

(3) Clearing, trimming, and prescribed burning activities are not allowed in endangered species habitat or critical habitat, regardless of season or time of year, except as indicated in an approved Endangered Species Management Plan (ESMP) or when supervised by qualified personnel from the ITAM Environmental Office.

(4) Untended or uncontrolled fires should be reported immediately to "Bullis Control."

Fort Sam Houston's INRMP (2001) states that management of these two bird species has little effect on military training. BCV habitat is mostly confined to the impact zone where there is no foot or mechanized traffic. The installation uses a Tactical Concealment Area (TCA) approach, which provides open areas for training while preserving GCW habitat. 


\section{Gray bat (Myotis grisescens) and Indiana bat (Myotis sodalis) - Federal Status: Endangered}

\section{Installation Occurrences}

Army installations with documented gray bat and Indiana bat populations on or in the immediate vicinity of the installations are listed in Table 4 (Rubinoff et al. 2004).

Table 4. Installations with gray and Indiana bat populations.

\begin{tabular}{|c|c|c|c|}
\hline Species & Installation & IMA & Location \\
\hline \multirow[t]{8}{*}{ Gray Bat } & Fort McClellan, AL & ARNG & Onsite \\
\hline & Tullahoma Training Site, TN & ARNG & Contiguous \\
\hline & Indiana Army Ammunition Plant, IN & BRAC & Onsite \\
\hline & Fort Leonard Wood, MO & NW & Onsite \\
\hline & Fort Campbell, KY & SE & Onsite \\
\hline & Fort Knox, KY & SE & Onsite \\
\hline & Holston Army Ammunition Plant, TN & SE & Onsite \\
\hline & Redstone Arsenal, AL & SE & Onsite \\
\hline \multirow[t]{11}{*}{ Indiana Bat } & Atterbury Training Site, IN & ARNG & Onsite \\
\hline & Macon Training Site, MO & ARNG & Contiguous \\
\hline & Tullahoma Training Site, TN & ARNG & Contiguous \\
\hline & Jefferson Proving Ground, IN & BRAC & Onsite \\
\hline & Picatinny Arsenal, NJ & NE & Onsite \\
\hline & Iowa Army Ammunition Plant, IA & NW & Onsite \\
\hline & Newport Chemical Activity, IN & NW & Onsite \\
\hline & Fort Leonard Wood, MO & NW & Onsite \\
\hline & Redstone Arsenal, AL & SE & Contiguous \\
\hline & Fort Campbell, KY & SE & Onsite \\
\hline & Fort Knox, KY & SE & Onsite \\
\hline
\end{tabular}

\section{Restrictions}

\section{Camp Atterbury}

Camp Atterbury has restrictions on training related to the use of smokes and obscurants as well as some general training constraints based on curtailing any increase of human disturbance in summer habitat. Between April 15 and September 15 there is a 36 -meter buffer zone around identified bat maternity roosts (trees) and a 120-meter buffer zone around water bodies. Within these zones smoke grenades and pots containing terephthalic acid (TPA, e.g., M83 or 18 smoke grenades) may be used only during daylight hours (USFWS 1998). The area of land restricted to 
smoke and obscurant use during the summer maternity season is approximately 8,600 ha or 32 percent of the installation's usable training land (Tetra Tech 2002). Smoke generators using hexachloroethane (HC) have been eliminated from use on the installation. Camp Atterbury has recognized that two training areas are suitable bat summer habitat, so the installation has determined that military training activities in these areas will not increase in intensity from current levels. These two areas represent 68 percent of installation land area (Shapiro and Hohmann, 2005).

\section{Fort Leonard Wood}

Fort Leonard Wood has also eliminated the use of HC-based smoke pots and grenades. The use of TPA-based devices is restricted within a 120-meter zone around waterways before sunrise and after sunset between March 15 and October 31. This buffer zone represents approximately 2,862 hectares or 1.4 percent of the installation (Shapiro and Hohmann, 2005; 3D/Environmental 1996b). In addition, Fort Leonard Wood has established "Endangered Bat Areas" around caves. These areas are a 162-meter radius around cave features and are limited to foot traffic (entering caves is off limits). In addition, Bat Management Zone 1 is from 162 to 457 meters around caves. Sound propagation and use of smokes and obscurants in this zone is prohibited during the times of year bats are using caves. Bat Management Zone 2 consists of a 1,932-meter radius around caves; sound production and habitat alteration is limited in this zone (Harland Bartholomew and Associations 1994, Delaney 2002, 3D/Environmental 1996a). These buffers equate to 130 hectares (0.52 percent of the installation) of training land during the summer when gray bat maternity colonies are onsite, and 280.3 hectares (1.1 percent of the installation) during the winter when Indiana bats are using their hibernacula (Shapiro and Hohmann 2005).

\section{Other Installations}

Camp Atterbury and Fort Leonard Wood appear to have the most severe restrictions based on endangered bat populations; however, several other installations have known restrictions on installation activities. Known restrictions include those on pesticide applications and related land management practices at Newport Chemical Activity, IN (McWilliams-Munson 1999 cited in Shapiro and Hohmann 2005) and noise considerations on some firing ranges at Iowa Army Ammunition Plant, IA. These installations do not support large volumes of training-related activities. 


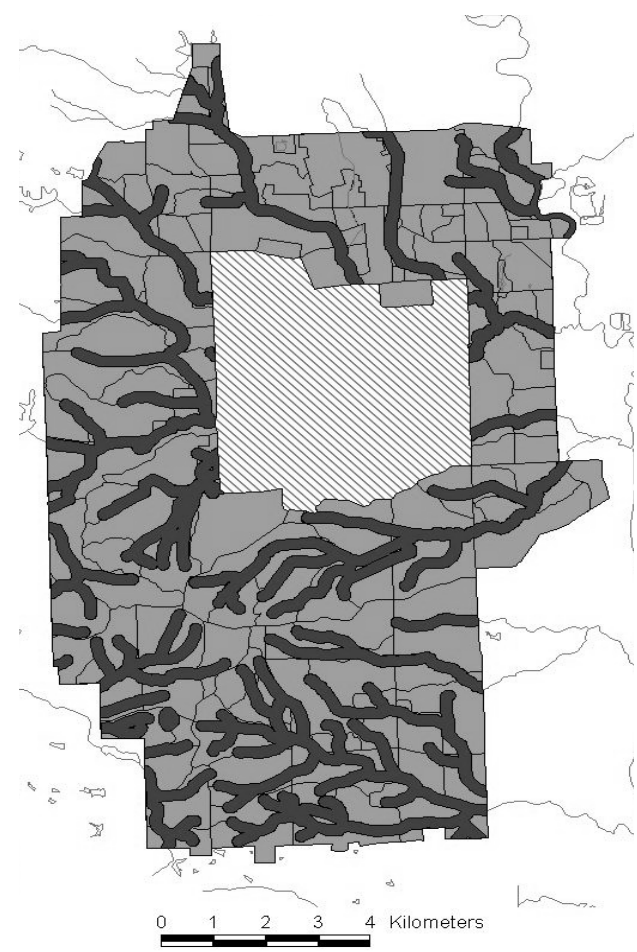

Figure 4. Buffer Zones (wide black strips) for TPA smoke restrictions along waterways, Camp Atterbury, IN.

(from Shapiro and Hohmann, 2005).
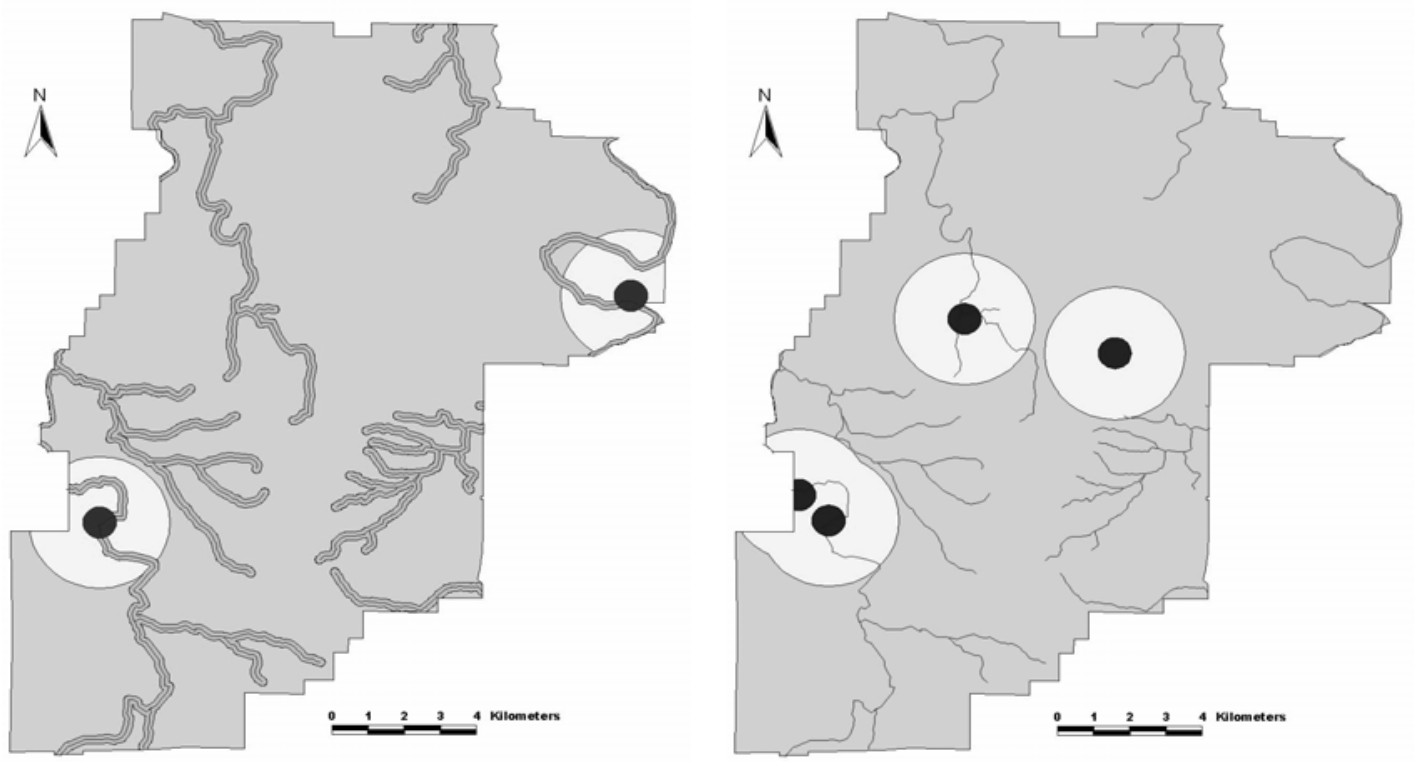

Figure 5. Fort Leonard Wood endangered bat related restrictions, left image depicts TPA smoke buffers on waterways and zones around gray bat maternity caves, right image depicts zones around Indiana bat hibernacula (caves). (from Shapiro and Hohmann, 2005). 


\section{Desert tortoise (Gopherus agassizii)- Federal Status: Threatened}

\section{Installations of Occurrence}

Army installations having desert tortoise populations are presented in Table 5 (Rubinoff et al. 2004).

Table 5. Installations with desert tortoise populations.

\begin{tabular}{|l|l|l|}
\hline Installation & IMA & Location \\
\hline Clark County Training Area, NV & ARNG & Contiguous \\
\hline Florence Military Reservation, AZ & ARNG & Onsite \\
\hline Fort Irwin, CA & SW & Onsite \\
\hline
\end{tabular}

\section{Restrictions}

Fort Irwin has recently acquired 118,674 acres in an expansion to allow for meeting training needs. Currently the expansion lands are closed to training due to desert tortoise populations. The Army is in consultation with USFWS regarding a translocation plan that would relocate tortoises on the installation to non-installation lands, with the exception of designated conservation areas. Pre-expansion installation acreage is over 642,000 acres; including restrictions on 20,000 acres of desert tortoise critical habitat that is off limits to all military activity with the exception of foot traffic (Delaney 2002). If the translocation proposal is successful, over 100,000 acres of the newly acquired land and over 19,000 acres of the pre-expansion lands would be opened to training (USFWS 2004).

Estimated acreages associated with land acquisition as reported in the USFWS Biological Opinion (USFWS 2004) include:

Expansion area:

Old lands free from restriction:
118,674 acres

19,643 acres

New areas for desert tortoise conservation within Fort Irwin:

UTM 90 Conservation Area Spur:

1,890 acres

UTM 90 Conservation Area West:

2,762 acres

UTM 90 Conservation Area East:

2,460 acres

Border Utility Corridor Buffer

4,560 acres 
Lane Mountain Milk Vetch New conservation areas:
Goldstone area:
2,471 acres
East Paradise Conservation Area:
4,300 acres

Note: Final Translocation plan is not complete; final acreages may vary.

Figure 6 provides an approximate location of the conservation areas. Restrictions within these conservation areas include: (1) No Mechanized Training, (2) No ground-disturbing activities, (3) No off-road travel, and (4) No new roads established unless needed to manage area.

In addition to restrictions on Fort Irwin, vehicle traffic is restricted to existing roads at the Clark County Training Area, NV (Delaney 2002).

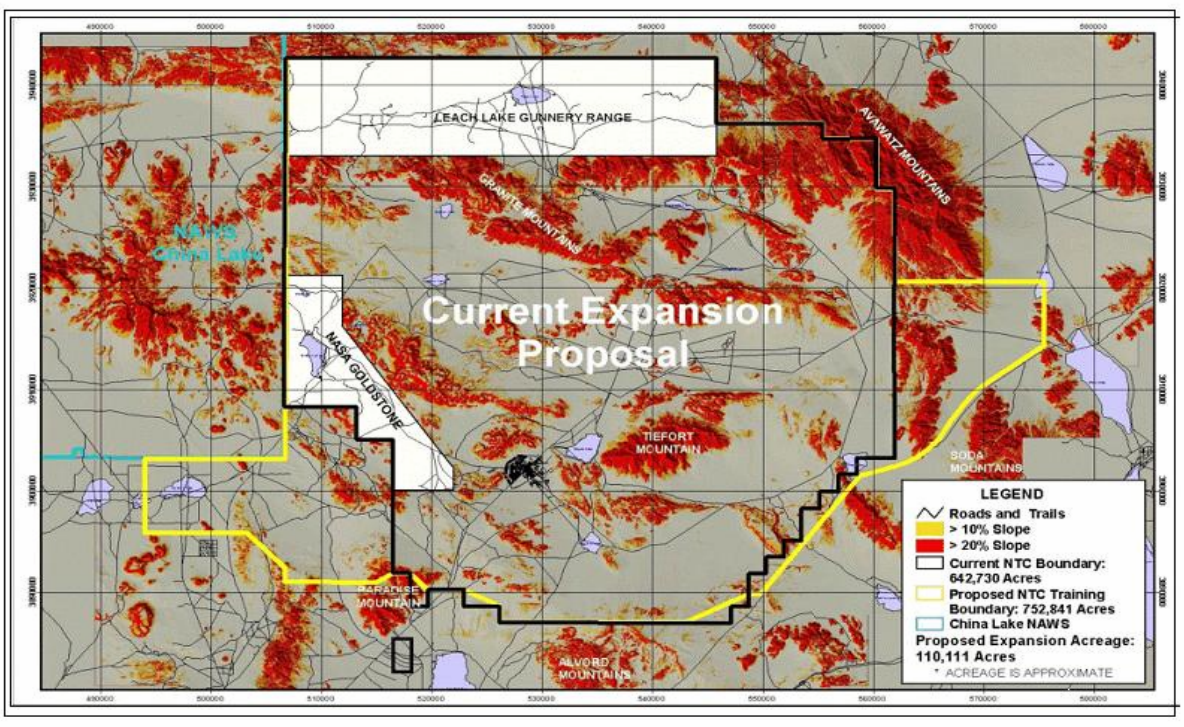

Figure 6. Locations of desert tortoise conservation areas on Fort Irwin, CA.

(Base map developed by ITAM Office, Fort Irwin, 2000.) 


\section{Gopher tortoise (Gopherus polyphemus) - Federal Status: Threatened}

\section{Installations of Occurrence}

The only installation with a federally listed Gopher tortoise population is Camp Shelby, MS (Rubinoff et al. 2004).

\section{Restrictions}

Training restrictions based on a 1988 Biological Assessment/1989 Biological Opinion (U.S. Army Corps of Engineers 2001) for Camp Shelby focus on restricting bivouac activity within a colony site. A colony site is defined as "all active/inactive burrows and a 200 foot buffer" (U.S. Army Corps of Engineers 2001). Areas with heavy bivouac use should be situated 300 meters (about 900 feet) from a colony boundary. Additionally, all equipment, vehicles (including tracked vehicles), and personnel should not get within 25 feet of any gopher tortoise burrow (both posted and unposted burrows; U.S. Army Corps of Engineers 2001). There are approximately 16,000 acres of suitable habitat on Camp Shelby. Due to the tortoise's transient nature, about 900 acres are under restriction at any one time (Delaney 2002). 


\section{Discussion}

Two important conclusions can be drawn from the information presented in this report: (1) TES restrict military training on installations to a quantifiable degree, and (2) over time, there is potential for many of these restrictions to be reduced.

Restrictions on training can be defined by some type of training activity that is prohibited or limited within a protected area, loss of combat realism, effects on combat readiness, loss of trainable acreage, or other variables that reflect a negative impact as a result of limitations encountered through the consideration of TES needs. All of these aspects are present from the restrictions encountered for managing the seven species discussed in this report; however, they vary greatly between species and installations. A common denominator for six of the seven species; BCV, GCW, gopher tortoise, desert tortoise, Indiana and gray bat, is restricted acreage. Additionally, for the cases presented in this report, a reduction of restricted acreage will most likely cause a decrease in the other measures of impacts (listed above).

Fort Hood currently has 14,871 hectares of GCW habitat and 4,184 hectares of BCV habitat with training limitation placed on them. Camp Atterbury and Fort Leonard Wood both suffer from reductions in training land usage due to endangered bat species. Camp Atterbury has restrictions placed on 68 percent of usable lands, while Fort Leonard Wood has reduced use of approximately 3,500 hectares. Gopher tortoise issues restrict over 16,000 acres of Camp Shelby lands, while over 100,000 acres of Fort Irwin expansion lands are currently unavailable to training as a result of desert tortoise presence. Because RCW clusters vary in size and tree spacing is not uniform, applying a 200-foot buffer around cluster sites does not automatically translate to a quantification of restricted acreage. However, as documented in this report, training usage is adversely affected on at least nine installations with RCW populations.

Active conservation management, research, and effective documentation have lead to reductions in military training-related restrictions on Army installations. Revised RCW management guidelines allow for greater training access to areas containing RCW clusters while allowing effective RCW management that would increase RCW populations. Additionally, data since 1997 show a positive trend in RCW population growth on installations, which could lead to future delisting. Currently, both Fort Hood and Fort Irwin are in consultation with the USFWS to reduce restrictions. Fort Hood's effort is to reduce core habitat of GCW to 3,861 hec- 
tares; elimination of designated core habitat for BCV is highly likely to succeed. This will reduce training constraints on over 90 percent of currently effected land. Translocating tortoises off Fort Irwin will open up over 100,000 acres to training activities. 


\section{Literature Cited}

1996 "Management Guidelines for the Red-cockaded Woodpecker on Army Installations" 30 October 1996. The 1996 Guidelines are available at:

https://www.denix.osd.mil/denix/Public/ES-Programs/Conservation/Woodpecker/woodp.html

AMEDDC\&S \& FSH Regulation No 350-2, Camp Bullis Training Regulation, Headquarters, U.S. Army Medical Department Center and School and Fort Sam Houston, Fort Sam Houston, TX, 1 March 2001.

Army Regulation (AR) 200-3, Environmental Quality - Natural Resources-Land, Forest and Wildlife Management, Headquarters Department of the Army, Washington, DC, 28 February 1995.

Cimprich, D.A. 2003. "The distribution of the black-capped vireo and its habitat on Fort Hood, Texas: The results of an installation-wide search." In: Endangered species monitoring and management at Fort Hood, Texas: 2003 Annual Report. The Nature Conservancy, Fort Hood Project, Fort Hood, TX.

Delaney, David K. 2002. Prioritization of Threatened and Endangered Species Sound Research on Army Installations. ERDC/CERL TR-02-30/ADA415008. U.S. Army Engineer Research and Development Center-Construction Engineering Research Laboratory (ERDC-CERL), Champaign, IL.

Endangered Species Act (ESA), 1973. Sections 1531 to 1544, title 16, United States Code (16 USC 1531-1544).

Harland Bartholomew and Associates. 1994. Final environmental assessment training area master plan. U.S. Army Engineer Center and Fort Leonard Wood, MO.

Hayden, Timothy J., John D. Cornelius, Howard J. Weinberg, Leslie A. Jette, and Robert H. Melton. 2001. Endangered Species Management Plan for Fort Hood, Texas: FY01-05, ERDC/CERL Technical Report TR-01-26/ADA387495, March 2001.

Hayden, Timothy J. 1997. Biological Assessment of the Effects of the Proposed Revision of the 1994 "Management Guidelines for the Red-cockaded Woodpecker on Army Installations". CERL Special Report 97/48/ADA322086, January 1997.

Integrated Natural Resources Management Plan for Fort Sam Houston and Camp Bullis Military Reservation. San Antonio Texas. 27 December 2001.

McWilliams-Munson, R. 1999. "Biological Opinion on the Agricultural Pesticide Application Practices at the Newport Chemical Depot, Newport, Indiana." Report submitted to the Department of the Army, April 131999 from the Bloomington Field Office, U.S. Fish and Wildlife Office. 
Rubinoff, Jay, Steven Sekscienski, and Bill Woodson. 2004. Installation Summaries from the FY 2003 Survey of Threatened and Endangered Species on Army Lands, Report number SFIM-AEC-TS-TR-2004005, April 2004. Available from http://aec.army.mil/usaec/natural/tes-fy03.pdf

Shapiro, Ann-Marie and Matthew G. Hohmann. 2005. Summary of Threatened and Endangered Bat-related Restrictions on Military Training, Testing, and Land Management, ERDC/CERL TR 05-13, June 2005 (in press).

Tetra Tech. 2002. Biological Assessment: Effects to Indiana Bats from Ongoing and Anticipated Future Military Activities. Report to Camp Atterbury, IN.

U.S. Army Corps of Engineers, Mobile District. 2001. Integrated Natural and Cultural Resources Management Plan and Environmental Assessment, Vol III. August 2001.

U.S. Fish and Wildlife Service (USFWS). 1998. Biological Opinion on the Construction and Operation of the Multi-Purpose Training Range (MPTR) at the Camp Atterbury Army National Guard Training Site, Edinburgh, Indiana. December 4, 1998.

USFWS. 2003. Recovery Plan for the Red-cockaded Woodpecker (Picoides borealis): second revision. U.S. Fish and Wildlife Service, Atlanta, GA. 296 pp.

USFWS. 2004. Biological Opinion for the Proposed Addition of Maneuver Training Lands at Fort Irwin, California (1-8-03-F-48), Ventura, CA.

3D/Environmental. 1996a. Impacts to Indiana Bats and Gray Bats from sound generated on training ranges at Fort Leonard Wood, Missouri. Biological Assessment of the Master Plan and Ongoing Mission. U.S. Army Engineer Center and Fort Leonard Wood, MO.

3D/Environmental. 1996b. Effects of certain aerosol contaminants on Indiana Bats and Gray Bats at Fort Leonard Wood, Missouri. Biological Assessment of the Master Plan and ongoing mission. U.S. Army Engineer Center and Fort Leonard Wood, MO. 


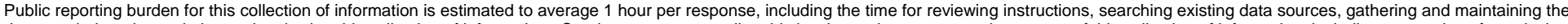

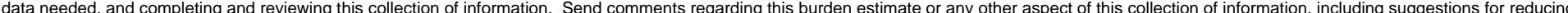

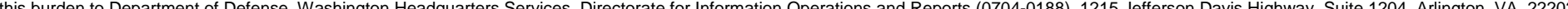

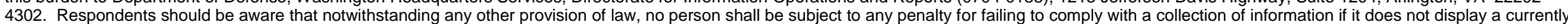
valid OMB control number. PLEASE DO NOT RETURN YOUR FORM TO THE ABOVE ADDRESS.
1. REPORT DATE (DD-MM-YYYY)
06-2005
2. REPORT TYPE

4. TITLE AND SUBTITLE

Training Restrictions on Army Lands Due to High Priority Endangered Species
3. DATES COVERED (From - To)

5a. CONTRACT NUMBER

5b. GRANT NUMBER

5c. PROGRAM ELEMENT NUMBER

5d. PROJECT NUMBER

622720 A 896

5e. TASK NUMBER

5f. WORK UNIT NUMBER

8. PERFORMING ORGANIZATION REPORT NUMBER

ERDC/CERL TR-05-12

U.S. Army Engineer Research and Development Center (ERDC)

Construction Engineering Research Laboratory (CERL)

PO Box 9005

Champaign, IL 61826-9005

\section{SPONSORING I MONITORING AGENCY NAME(S) AND ADDRESS(ES)}

Department of the Army

Office of the Director of Environmental Programs

600 Army Pentagon

Washington, DC 20310-0600

10. SPONSOR/MONITOR'S ACRONYM(S)

DAIM-ED-N

11. SPONSOR/MONITOR'S REPORT NUMBER(S)

\section{DISTRIBUTION / AVAILABILITY STATEMENT}

Approved for public release; distribution is unlimited.

\section{SUPPLEMENTARY NOTES}

Copies are available from the National Technical Information Service, 5285 Port Royal Road, Springfield, VA 22161.

\section{ABSTRACT}

Abstract: The Endangered Species Act requires that Federal agencies conserve Threatened and Endangered Species (TES), and in consultation with the U.S. Fish and Wildlife Service or the National Marine Fisheries Service, ensure their actions are not likely to jeopardize the continued existence of any TES or result in the destruction or adverse modification of critical habitat. Guidance for TES management can produce restrictions that interfere with realistic combat training conducted on Army installations.

The U.S. Army Environmental Requirements and Technology Assessments (AERTA) research is focused on seven of the highest priority TES. These species are: red-cockaded woodpecker (Picoides borealis), black-capped vireo (Vireo atri-capillus), golden-cheeked warbler (Dendroica chrysoparia), gray bat (Myotis grisescens), Indiana bat (Myotis sodalis), desert tortoise (Gopherus agassizii), and gopher tortoise (Gopherus polyphemus).

This document provides a current depiction of TES-related restrictions on Army installations that have populations of the seven priority TES and are, or have been, the focus of ERDC-CERL research efforts. Two important conclusions can be drawn from the information presented in this report: (1) TES restrict military training on installations to a quantifiable degree, and (2) over time, there is potential for many of these restrictions to be reduced.

\begin{tabular}{|c|c|c|c|c|c|}
\hline $\begin{array}{l}\text { 15. SUBJECT TEF } \\
\text { threatened speci } \\
\text { TES }\end{array}$ & & $\begin{array}{l}\text { endangered st } \\
\text { military traini }\end{array}$ & & natural re & urces management \\
\hline 16. SECURITY CL & IFICATION OF: & & $\begin{array}{l}\text { 17. LIMITATION } \\
\text { OF ABSTRACT }\end{array}$ & $\begin{array}{l}\text { 18. NUMBER } \\
\text { OF PAGES }\end{array}$ & $\begin{array}{c}\text { 19a. NAME OF RESPONSIBLE PERSON } \\
\text { Patrick J. Guertin }\end{array}$ \\
\hline $\begin{array}{l}\text { a. REPORT } \\
\text { Unclassified }\end{array}$ & $\begin{array}{l}\text { b. ABSTRACT } \\
\text { Unclassified }\end{array}$ & $\begin{array}{l}\text { c. THIS PAGE } \\
\text { Unclassified }\end{array}$ & SAR & 30 & $\begin{array}{l}\text { 19b. TELEPHONE NUMBER } \\
\text { (include area code) } \\
\text { (217) } 352-6511 \times 5857\end{array}$ \\
\hline
\end{tabular}

